\title{
Determinants of Workers' Remittances : The Case of Turkey
}

\section{OSMAN TUNCAY AYDAS, KIVILCIM METIN-OZCAN \& BILIN NEYAPTI}

To cite this article: OSMAN TUNCAY AYDAS , KIVILCIM METIN-OZCAN \& BILIN NEYAPTI (2005) Determinants of Workers' Remittances : The Case of Turkey, Emerging Markets Finance and Trade, 41:3, 53-69, DOI: 10.1080/1540496X.2005.11052609

To link to this article: https://doi.org/10.1080/1540496X.2005.11052609

曲 Published online: 07 Dec 2014.

Submit your article to this journal $\pi$

Џlll Article views: 109 
Emerging Markets Finance and Trade, vol. 41, no. 3, May-June 2005, pp. 53-69.

(C) 2005 M.E. Sharpe, Inc. All rights reserved.

ISSN 1540-496X/2005 \$9.50+0.00.

\title{
OSMAN TUNCAY AYDAS, KIVILCIM METIN-OZCAN, AND BILIN NEYAPTI
}

\section{Determinants of Workers' Remittances}

\author{
The Case of Turkey
}

\begin{abstract}
Workers' remittance flows to Turkey have dramatically increased since the $1960 \mathrm{~s}$, constituting a significant proportion of imports. The empirical evidence in this paper indicates that black market premium, interest rate differential, inflation rate, growth, home and host country income levels, and periods of military administration in Turkey have significantly affected these flows. Among them, the negatively significant effects of the black market premium, inflation, and a dummy for periods of military administration point at the importance of sound exchange rate policies and economic and political stability in attracting remittance flows. In addition, both investment and consumption-smoothing motives are observed, though the former of which appears more prevalent after the 1980s.
\end{abstract}

Key words: remittances, Turkey.

According to the estimates of the International Labor Organization, there were 36 million to 42 million migrant workers worldwide in 1999. Remittances are the main reason for workers to seek employment abroad (Murinde 1993). ${ }^{1}$ As a major source of foreign exchange in many developing countries, workers' remittance (WR) flows are likely to become an increasingly important outcome of global economic integration. Neyapti (2004) reports that in countries such as Lebanon, Samoa, Yemen, Cape Verde, Jordan, Tonga, Albania, and El Salvador, WR receipts exceeded 10 percent of gross domestic product (GDP) during the 1990s; in countries such as Hungary, Egypt, Morocco, and Sri Lanka, they exceeded 5 percent of GDP; and in

Osman Tuncay Aydas recently received his master's degree from Bilkent University; Kivilcim Metin-Ozcan (kivilcim@ @ilkent.edu.tr) is an associate professor, and Bilin Neyapti (neyapti @ bilkent.edu.tr) is an associate professor at Bilkent University, Ankara. They thank two anonymous referees of this journal for their comments. 
countries such as Nicaragua, Portugal, Tunisia, Georgia, Croatia, Nigeria, and Turkey, they exceeded 2 percent of GDP. Neyapti also observes that, during the 1990s, WR receipts in many developing countries have been many-fold greater than other forms of foreign exchange inflows, such as foreign direct investment and other net long-term or short-term capital flows. ${ }^{2}$

In view of the increasing global economic integration, which leads to the increasing volume of WR and thus to WR's growing potential to affect domestic economies via current account financing, it is important to ascertain the determinants of WR flows. The literature presents the analysis of the determinants of WR under two main categories: those that are related to sociodemographic characteristics, and those that are economic, political, and institutional in nature. Among the macroeconomic determinants of WR, while the literature agrees on the impact of variables such as income and worker stock in the host country, there is disagreement on the impact of such variables as domestic income, inflation, exchange rate premium, and relative interest rates.

This study focuses on the determinants of WR flows to Turkey, a considerably large developing country. In Turkey, WR followed a generally increasing trend since the 1980s, though not as a share of GDP. Considering the significant changes of direction in worker migration and economic circumstances, Turkey provides a rich case study of the determinants of WR. To our knowledge, the only other study on Turkey in that regard is that by Straubhaar (1986), which the current study builds upon, both with regards to data and econometric modeling. This study may thus shed light on the policies and economic circumstances that facilitate remittance flows.

We investigate the effect on WR flows to Turkey of various macroeconomic variables, particularly the black market premium, interest differentials, and per capita income in the home and host countries, besides variables that are related to economic and political risk. Based on a time-series analysis using data for the 1964-93 period, our empirical analysis suggests that macroeconomic and political stability, particularly implied by black market premium, inflation, growth, and military administration, have significantly affected remittance flows to Turkey.

That much of WR are channeled into developing countries through informal mechanisms (El-Sakka and McNabb 1999) cautions against the quality of available data. Due to this common data deficiency, cross-sectional empirical analysis of WR could, in fact, merely emphasize the "official" aspect of its measurement, which is also the case here.

\section{Historical Account of the Turkish Economy and WR}

\section{Trends in WR Flows to Turkey}

Aydas (2002) reports that Turkish workers' migration, mainly to Western Europe, and particularly to the Federal Republic of Germany, started in the early 1960s. ${ }^{3}$ 
Since then, over 2 million Turkish workers seeking employment have migrated to about thirty countries. The records of the Turkish Employment Service show that after the mid-1970s, the flow of Turkish workers to Europe stagnated and was directed instead toward the Arabic peninsula and toward Russia after 1990. Figure 1 shows the trend in Turkish WR for the period of 1964 to 2000. Before 1963, remittances of Turkish emigrants toward their home country were so small that they were not recorded in the Turkish balance of payments. The flow of remittances started to grow slowly only after 1964, gradually becoming an important source of external financing for Turkey.

According to the State Statistical Institute of Turkey, the ratio of WR to total exports was 20 percent in 1970, reached a peak of 90 percent in 1976, and has remained around 20 percent since 1990. WR as a percentage of GDP has remained barely over 2 percent until 2000. Nevertheless, accounting for about 10 percent of imports since 1990s, WR still appears to be an important financing item.

\section{Economic and Political Context}

The economic and political context in Turkey during the 1960-1980 period is closely connected to the trends in Turkish workers' migration. When Turkey undertook planned development in 1963, the country was dominantly agricultural. Agriculture accounted for about 41 percent of the national income, while over 80 percent of exports were agricultural products. In addition, agriculture accounted for three-quarters of the Turkish labor force, which then amounted to almost 12 million (Paine 1974). ${ }^{4}$

Rapid industrialization and economic growth were the main concepts for the three periods of development planning, from 1963 to 1977. Although the first two of the five-year development plans were reasonably successful in achieving their aggregate targets (in particular, an average annual growth rate of 7 percent), they were less successful in bringing about basic structural transformation in the economy, or in distributing the gains from development to those most in need. In addition, price stability was not achieved, and employment generation was not sufficient; the unemployment index rose from 100 in 1962 to 162 in 1972, and the nonagricultural unemployment index from 100 to 319 during the same period. In 1973, estimated unemployment reached 12.5 percent of the economically active population. Because of these developments and in view of the inflow of savings and remittances, exporting workers became an increasingly attractive policy to the government. The outflow of migrant workers was primarily determined by hostcountry demand and so was subject to large fluctuations. Paine indicates that "Despite the high risk attached to the adoption of a mass labor export policy, the achievement of Turkey's development plans was made increasingly dependent on labor export" (1974, p. 36).

Although the planned-economy period was associated with the growth of industrial output and gross national product, it also had some important drawbacks. 
Figure 1. Turkish Workers' Remittances, 1964-2000 (in US\$ millions)

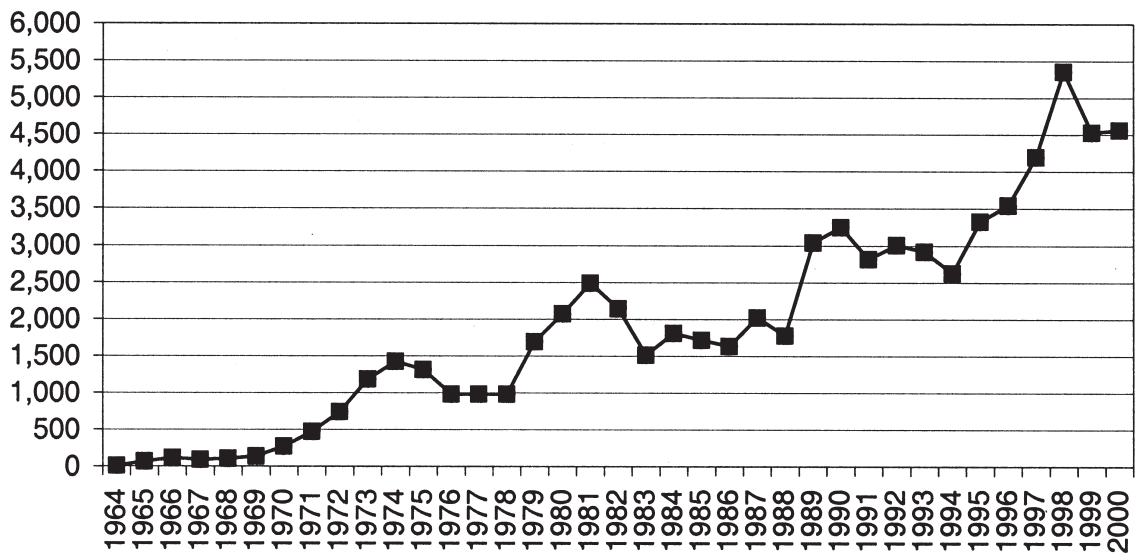

Industrialization in Turkey took place mainly in large-scale, capital-intensive industries with high-quality technological equipment, bearing two consequences that were important for emigration. First, this form of industrialization created relatively little employment (Aydas 2002). Meanwhile, the population grew, and labor used in the agricultural sector decreased, resulting in increased migration as official unemployment continued to rise during 1962-77. Second, although the process of industrialization was intended to support national self-sufficiency, the opposite was realized; Turkey became strongly dependent on other countries for raw materials, semimanufactured articles, and technology. Hence, lack of foreign currency and balance-of-payment deficits formed a great problem. Adler (1981) notes that the policy priority was on attracting hard currency via labor export. On the contrary, political instability caused an unstable economic environment that led to a deterioration in remittances. ${ }^{5}$

Figure 1 shows that WR to Turkey declined dramatically after 1974, coinciding with world oil crises and pursuant to increased inflation. WR started to recover in mid-1979 as the government began to devalue the Turkish lira in a first attempt to correct a large exchange rate misalignment. However, both political turmoil and the failure to effectively correct the misalignment brought remittances back to very low levels in the last months of 1979. Yearly figures show a recovery in remittances only after a new economic program was implemented in the early 1980s (Elbadawi and Rocha 1992). Though the remittance flow declined in the early 1980s during military administration, it stabilized in the second half of the decade and rose substantially in the 1990s, following the country's financial crisis in 1994. Interestingly, however, the flow declined in 1999, a year marked by devastating earthquakes in western Turkey, which suggests the dominance of the investment motive rather than the motive of smoothing the consumption of families left behind to be the main motive for migrant remittances. 


\section{Macroeconomic and State Policy}

As substantial political turmoil in Turkey was seen in the period between 1960 and 1980 workers, remitted substantially less during the years of government change, which also portrayed changes in the official attitude toward the remittances. How change in government led to change in the official attitude toward the remittances is described at length in Miller (1976), Etzinger (1978), Werth and Yalçıntaş (1978), Adler (1981), and Penninx (1982).

To encourage migrants' remittances, Turkish governments implemented a number of policies, such as special exchange rates for remittances, special interest rates for foreign currency accounts at the central bank (the Dresdner scheme), and a program that permits Turks residing abroad to shorten their compulsory military service by paying a fee in foreign currency. ${ }^{6}$ In addition, Turkish migrants enjoyed special import privileges for consumer goods and machinery. Moreover, since the late 1980s, returned migrants have had the right to buy consumer durables with foreign currencies at special duty-free shops during the first six months after their return (Martin 1992).

Preferential exchange rates for emigrants' remittances were practiced in the 1960s, abolished in 1970, and became effective again in April and May 1979. Turkey adopted a two-tier exchange rate in May 1979, which increased remittances for a short time, and then devalued the Turkish lira in 1980, which once again increased remittances.

During the 1970s, Turkish governments also tried to channel remittance savings into employment-generating activities. Such governmental channeling of remittances included programs of Turkish lira-denominated loans for homes, farms, and small businesses, contingent on migrants establishing foreign-currency savings accounts with designated Turkish banks. Migrants wanting to return with cars, trucks, and professional equipment were also required to open foreign-currency savings accounts. Turkey also established two unique development programs linked to migration: village development cooperatives, which were initiated in 1962 both to help rural development and to give priority to members who wished to migrate abroad for employment, and Turkish workers corporations. However, according to Abadan-Unat (1976), such programs to channel remittances into government-approved investments failed to attract many migrant applicants, in part because the private sector offered attractive savings alternatives, and savings are more often used for housing than investment (see also Russell 1986).

When labor demand in Western Europe suddenly decreased in the beginning of the 1970s, in order to promote the departure of migrants, host countries adopted bilateral credit and reintegration programs. These programs failed to attract many participants, however. An agreement between the Federal Republic of Germany and Turkey in 1972 made German funds available to returning Turkish migrants who wished to open a small business in Turkey, provided that the migrant participated in training programs in both Germany and Turkey. One analysis of such reintegration 
programs by host nations to promote migrant returns concluded that they were too complicated and too costly for host governments and not attractive enough to encourage migrant participation (Martin 1992).

\section{Review of Literature on the Determinants of WR}

The literature groups the determinants of WR in two main categories (see, for example, Russell 1986). The first category concerns the sociodemographic characteristics of migrants and their families. The second category of determinants, on the other hand, considers macroeconomic and political variables as well as variables related to the institutional environment.

A large part of the existing literature (see, for example, Hoddinott 1992; Knowles and Anker 1981; Lucas and Stark 1985) focuses on the first group of determinants of WR rather than on the macroeconomic variables that may influence the flow of migrants' savings to the home country. According to Russell, potential sociodemographic determinants of WR are the ratio of females in the population of the host country; years since worker has migrated; migrant household income level; employment of other household members; marital status of the migrant; years of education of the migrant; and, occupational level of the migrant. To this list, using a household survey data, Ilahi and Jafarey (1999) add variables such as the number of children and their educational position, and the premigration economic situation.

Such sociodemographic determinants have a close relationship with the motives to remit. Lucas and Stark (1985) point out that the motives to remit can be purely altruistic, may originate from self-interest, or may be due to a mutually beneficial agreement between the migrant and the family in the home country. Within this context, one approach to analyzing remittance decisions has been to model the migrant workers' saving function (see, for example, Djajic 1989; Djajic and Milbourne 1988), and another approach has been to view remittances as an intertemporal contractual agreement.?

The second strand of the literature that focuses on the macroeconomic determinants of WR emphasizes the number of workers, wage rates, economic activity in host and home countries, exchange rates, relative interest rate between labor-sending and -receiving countries, political risk factors in the sending country, and facilities for transferring funds (see Russell 1986). Among them, the level of economic activity, real earnings of workers, and the total number of workers in the host country were consistently found to have a significant and positive effect on the flow of remittances (see, for example, Elbadawi and Rocha 1992; El-Sakka and McNabb 1999; Straubhaar 1986; Swamy 1981).

The evidence on the impact of relative rates of return, exchange rate premium, domestic income and inflation is rather mixed, however. ${ }^{8}$ While Swamy (1981), Straubhaar (1986), and Glytsos (1988) argue that neither interest rate differentials between the host and home countries nor the variation in exchange rates have any 
effect on remittance flows, Katselli and Glytsos (1986) find per capita remittances to be related to the interest rate in the host country. According to Chandavarkar (1980), both realistic exchange rates and the existence of sufficient financial facilities significantly affect remittances. Wahba (1991) also indicates that black market premiums, interest rate differentials, political stability, consistency in government policies, and financial intermediation all significantly affect the flow of remittances. However, while El-Sakka and McNabb (1999) and Elbadawi and Rocha (1992) agree on the negative effect of the black market premium, they disagree on the effects of differential interest rate and domestic inflation. According to Elbadawi and Rocha, the differential between domestic and foreign interest rates has no significant effect on remittances, while El-Sakka and McNabb argue that it negatively affects the remittances. Moreover, both Katselli and Glytsos and Elbadawi and Rocha find a significant negative effect of inflation on WR flows, while ElSakka and McNabb argue that it has a positive effect.

As El-Sakka and McNabb indicate, the contradictory findings reported in the literature may reflect the fact that the focus of some of these studies is often limited to only a few macroeconomic variables, ignoring key determinants such as the black market exchange rate. In addition, due to the lack of data, the estimation periods of most of the studies are rather short. Also, in various studies (Elbadawi and Rocha 1992; El-Sakka and McNabb 1999), the estimation of remittance flows is based on levels of potential determinant variables that are generally nonstationary. All these factors lead us to question the reliability of the general conclusions in previous literature.

A study that is especially relevant for the current one is by Straubhaar (1986), who analyzes determinants of remittances of Turkish workers in Germany. His main findings are the significant impact on remittances of the economic situation in Germany and, the confidence of workers in the safety and liquidity of investments in Turkey, and not so much on the investment incentives provided by the Turkish government. The current study differs from that of Straubhaar's, first in the time period studied (1963-82), which entails many changes since then with regard to the demographic structure and family ties of workers abroad, as well as changes in the economic environment; and, second, the coverage of WR is different in the two studies, as we consider WR not only from Germany but in total WR flows to Turkey, whose origin has changed significantly over time. Furthermore, our estimation method differs from that of Straubhaar in that we employ not only a larger set of variables but also short-run modeling.

To summarize, while the evidence in the literature consistently shows the significant influence on remittances of various sociodemographic characteristics of migrants and their families, evidence regarding the impact of macroeconomic variables—such as interest rate differentials, black market premiums, and domestic rate of inflation-on remittances is not conclusive. As there has not been a study of the determinants of WR in Turkey after 1982, we do that next by also employing time-series modeling. 


\section{Data and Methodology}

In view of the existing literature and considering the historical background of the Turkish economy, we present a model to analyze the macroeconomic determinants of WR in Turkey. The following is a brief summary of the hypotheses behind the variables we employ in our model. Previous studies suggest that host-country income is a significant determinant of WR due to both increased quantity demanded of the migrant labor and increase in the wages offered to them. ${ }^{9}$ The stock of workers abroad is also argued to positively affect WR. The income level of the migrants' country of origin may affect WR either positively or negatively, however, depending on different motives to remit (roughly speaking, investment or consumption-smoothing motives). Similarly, both growth and inflation in the economy of origin may affect WR in either way: if investment is the main motive to remit, the effect of the first would be positive, and the latter would be negative. However, if concern for family in the country of origin is the main motive to remit, opposite results could arise. The effect of a high interest rate differential is also ambiguous for two reasons: while high interest rates may provide incentives for WR, they may also reflect economic instability and high risk. Likewise, while the existence of a parallel market for exchange rates may provide incentives for WR via more realistic rates, it also increases the remittance costs of using official channels, and, therefore, its effect on WR as a whole is ambiguous. Especially in the absence of a black market for currency exchange rates, a real overvaluation of home-country currency would be a deterrent to WR flows.

Accordingly, the list of variables employed in this study are official cash remittances (REM), stock of workers abroad (WORKER), per capita income of Turkey $(Y D O M)$, black market premium $(B M P)$, real overvaluation $(R O V)$, domestic inflation $(I N F)$, domestic growth $(G R O W T H)$, and a dummy variable that takes the value of one in the years of military regimes and zero otherwise (EXGOVDUM). In addition, we consider eleven countries that have the largest stock of Turkish emigrants, which we use as weights to calculate "host-country per capita income" $(Y H O S T)$ and interest rate differential (INTDIF). ${ }^{10}$ The Appendix provides the list of variables along with their definitions, units, sources from which they are obtained, and the periods they cover.

Augmented Dickey-Fuller (ADF) unit root tests reported in Table 1 indicate that all variables of interest, other than EXGOVDUM and GROWTH, are integrated of order one, that is $I(1)$. Hence, throughout the paper, we use the first differences for these variables.

We note that black market premium and real overvaluation are highly correlated in a positive direction. Real overvaluation is also negatively correlated with an extra government dummy. These correlations should be kept in mind in interpreting the regression results, because they may affect the direction and significance of the impact of these variables on the dependent variable. 
Table 1

\section{Augmented Dickey-Fuller Test Results}

\begin{tabular}{|c|c|}
\hline Variables $^{2}$ & $\begin{array}{c}\text { ADF }^{1} \\
\text { Test-statistic }\end{array}$ \\
\hline $\mathrm{BMP}^{+}$ & $-2.17(0)$ \\
\hline$\Delta \mathrm{BMP}^{++}$ & $-4.02(0)^{\star \star \star}$ \\
\hline LOGYHOST & $-1.55(1)$ \\
\hline$\triangle \mathrm{LOGYHOST}$ & $-3.71(0)^{\star \star \star}$ \\
\hline LOGYDOM & $-2.07(0)$ \\
\hline$\triangle \mathrm{LOGYDOM}=\mathrm{GROWTH}$ & $-5.92(0)^{\star \star \star}$ \\
\hline LOGREM & $-2.25(0)$ \\
\hline$\triangle$ LOGREM & $-4.17(0)^{\star \star \star}$ \\
\hline LOGREMpw & $-1.96(0)$ \\
\hline$\Delta$ LOGREMpw & $-4.35(0)^{\star \star \star}$ \\
\hline INTDIF & $0.01(0)$ \\
\hline$\Delta$ INTDIF & $-3.42(0)^{\star \star}$ \\
\hline INF & $-2.17(0)$ \\
\hline$\Delta \mathrm{INF}$ & $-7.53(0)^{\star \star \star}$ \\
\hline ROV & $-1.81(0)$ \\
\hline$\Delta \mathrm{ROV}$ & $-5.07(0)^{\star \star \star}$ \\
\hline EXGOVDUM & $-2.73(0)^{\star \star}$ \\
\hline
\end{tabular}

Notes: ${ }^{1}$ The usual advice is to include a number of lags sufficient to remove serial correlation in the residuals. Hence, when trying up to four lags in the augmented DickeyFuller (ADF) equation for all variables, it is observed that for all variables, other than YHOST, autocorrelation is eliminated at $0 \mathrm{lag}$, as reported in the parentheses, meaning that DF tests coincide with the augmented ADF tests. For YHOST, the DF test result is $0.40(0) .{ }^{2} L O G$ and $\Delta$ indicate the logarithm and the first difference of the variables, respectively. ${ }^{+}$Level regressions have a constant and a trend; ${ }^{++}$first difference equations have only a constant term. *** and $* *$ indicate significance at the 1 and 5 percent significance levels, respectively.

We use ordinary least squares to estimate two models that are only distinguished on the basis of the two definitions of WR: WR receipts per worker (REMpw), and WR flows $(R E M)$. All the variables used in the estimation, except for EXGOVDUM, are used in first differences because they are $I(1)$. In addition, because we are interested in the effect of the levels of incomes on WR, as well as their rates of growth, we use levels for both domestic and host incomes. ${ }^{11}$ Hence, the following model is estimated for the two dependent variables LOGREM and LOGREMpw: ${ }^{12}$ 


$$
\begin{aligned}
& \Delta \operatorname{LOGREM}(\mathrm{pw})_{t}=\beta_{0}+\beta_{1} \Delta B M P_{t}+\beta_{2} \Delta I N F_{t}+\beta_{3} \Delta R O V_{t} \\
& +\beta_{4} \Delta I N T D I F_{t}+\beta_{5} \text { GROWTH }_{t}+\beta_{6} \text { EXGOVDUM }_{t} \\
& +\beta_{7} \text { LOGYHOST }_{t}+\beta_{8} \text { LOGYDOM }_{t}+\varepsilon_{1 t} \text {. }
\end{aligned}
$$

\section{Empirical Results}

In this section, we report and discuss the results of the estimation of the model presented above. Because the data on interest rate differential (INTDIF) are not available until 1978, we consider two different estimation periods, 1965-93 and 1979-93, the latter of which includes INTDIF ${ }^{13}$ while the former does not. In addition, we do not consider more recent years, because data on black market premiums (BMP) are not available after 1994, a year of major financial crises in Turkey, which was followed by other financial and economic crises in the country in the second half of the 1990s.

Regression results reported in Table 2 indicate that, during the 1965-93 period, $R O V$ appears significant at the 1 percent level, and both $B M P$ and YDOM appear significant at the 5 percent level. Hence, the evidence indicates that, during this period, remittances flowed to Turkey in order to compensate for negative income shock-that is, with the consumption-smoothing motive, as the positive effect of real overvaluation on remittances reinforced this effect. The negative effect of $B M P$ on remittances indicates that exchange rate controls discouraged remittances.

The estimation of the model for the 1979-93 period, with the inclusion of the variable INTDIF, leads to rather interesting results, and with a much greater goodness of fit of 0.78. While the negative effects of $B M P$ and $Y D O M$ have now become significant at 1 percent, ROV loses its significance, and EXGOVDUM and YHOST now become significant at the 1 percent and 5 percent levels, respectively. The loss of significance in $R O V$ can be explained by the presence of a more liberal exchange rate system since the 1980s. In addition, INTDIF is significantly positive, indicating that higher interest rates in Turkey attracted remittances. On the other hand, the negative significance of EXGOVDUM indicates that political instability has been an influential factor in discouraging remittance flows. During this period, consumption-smoothing effects are still evident in the negative coefficient on YDOM and positive coefficient of YHOST, which are both significant at the 1 percent and 5 percent levels, respectively.

Next, we estimate the model for LOGREM, where we also control for the stock of workers abroad (WORKER). This specification leads to higher goodness of fits of 0.70 and 0.88 for the two periods, respectively (see Table 3 ). However, WORKER appears to affect remittance flows only in the earlier period, 1965-93, which is not surprising considering that the family ties of workers living abroad with the home country are likely to have weakened significantly over time.

While the significance of ROV in the period 1965-93, and BMP, INTDIF, YDOM, 
Table 2

OLS Results Using First Differences of Variables (dependent variable: $\Delta$ LOGREMpw)

\begin{tabular}{|c|c|c|}
\hline \multirow[b]{2}{*}{ Explanatory variables } & \multicolumn{2}{|c|}{ Data period } \\
\hline & $1965-1993$ & 1979-1993 \\
\hline \multirow[t]{2}{*}{ C } & $16.66^{\star \star \star}$ & $32.32^{\star \star \star}$ \\
\hline & $(2.13)$ & $(2.90)$ \\
\hline \multirow[t]{2}{*}{$\Delta \mathrm{BMP}$} & $-0.009^{\star \star}$ & $-0.02^{* * *}$ \\
\hline & $(-2.18)$ & $(-3.01)$ \\
\hline \multirow[t]{2}{*}{$\Delta \mathrm{INF}$} & -0.0002 & -0.0038 \\
\hline & $(-0.05)$ & $(-1.52)$ \\
\hline \multirow[t]{2}{*}{$\Delta I N T D I F$} & - & $1.94^{*}$ \\
\hline & & $(1.85)$ \\
\hline \multirow[t]{2}{*}{$\Delta \mathrm{ROV}$} & $0.016^{\star \star \star}$ & 0.009 \\
\hline & $(2.18)$ & $(1.26)$ \\
\hline \multirow[t]{2}{*}{ EXGOVDUM } & -0.076 & $-0.91^{\star \star *}$ \\
\hline & $(-0.49)$ & $(-3.37)$ \\
\hline \multirow[t]{2}{*}{ GROWTH } & 0.005 & 0.034 \\
\hline & $(0.19)$ & $(1.44)$ \\
\hline \multirow[t]{2}{*}{ LOGYDOM } & $-6.80^{\star \star}$ & $-14.32^{\star \star \star}$ \\
\hline & $(-1.91)$ & $(-2.79)$ \\
\hline \multirow[t]{2}{*}{ LOGYHOST } & 1.13 & $3.05^{\star \star}$ \\
\hline & $(1.38)$ & $(2.43)$ \\
\hline$R$-squared & 0.38 & 0.78 \\
\hline Adjusted $R$-squared & 0.18 & 0.50 \\
\hline$F$ test & $1.89^{*}$ & $2.73^{*}$ \\
\hline
\end{tabular}

Notes: Figures in parentheses are the $t$-ratios. $* * *, * *$, and $*$ indicate significance at the 1,5 , and 10 percent significance levels, respectively.

YHOST, and EXGOVDUM in the period 1979-93, remain, the significance of BMP and YDOM (though they still remain negative) disappears in the 1965-93 period. On the other hand, we observe that both INF and GROWTH become significant in the 1973-93 period, with negative and positive signs, respectively. The significance of INF and GROWTH as indicators of economic stability in explaining total remittance flows, combined with earlier observations, indicates that investment, along with the motive of consumption smoothing, has become an effective motive for remittance flows in Turkey after 1979.

Overall, the findings of the empirical analysis indicate that both economic and political stability have positively influenced remittance flows to Turkey-especially after 1979 , showing that the motives for remittances have predominantly 
Table 3

OLS Results Using First Differences of Variables (dependent variable: $\triangle \mathrm{LOGREM)}$

\begin{tabular}{|c|c|c|}
\hline \multirow[b]{2}{*}{ Explanatory variables } & \multicolumn{2}{|c|}{ Data period } \\
\hline & 1965-1993 & 1979-1993 \\
\hline \multirow[t]{2}{*}{ C } & 5.33 & $18.06^{\star \star \star}$ \\
\hline & $(1.64)$ & $(4.17)$ \\
\hline \multirow[t]{2}{*}{$\triangle$ LOGWORKER } & $0.86^{\star \star \star}$ & -0.28 \\
\hline & $(4.52)$ & $(-0.81)$ \\
\hline \multirow[t]{2}{*}{$\Delta \mathrm{BMP}$} & -0.003 & $-0.0087^{\star \star \star}$ \\
\hline & $(-1.50)$ & $(-3.63)$ \\
\hline \multirow[t]{2}{*}{$\Delta \mathrm{INF}$} & -0.0005 & $-0.0027^{\star * *}$ \\
\hline & $(-0.5)$ & $(-2.70)$ \\
\hline \multirow[t]{2}{*}{$\Delta$ INTDIF } & - & $0.961^{\star \star \star}$ \\
\hline & & $(2.60)$ \\
\hline \multirow[t]{2}{*}{$\Delta \mathrm{ROV}$} & $0.007^{\star \star \star}$ & 0.002 \\
\hline & $(3.00)$ & $(0.73)$ \\
\hline \multirow[t]{2}{*}{ EXGOVDUM } & -0.027 & $-0.47^{\star \star \star}$ \\
\hline & $(-0.44)$ & $(-4.69)$ \\
\hline \multirow[t]{2}{*}{ GROWTH } & 0.002 & $0.017^{\star *}$ \\
\hline & $(0.22)$ & $(2.07)$ \\
\hline \multirow[t]{2}{*}{ LOGYDOM } & -2.29 & $-8.136^{\star \star \star}$ \\
\hline & $(-1.58)$ & $(-4.06)$ \\
\hline \multirow[t]{2}{*}{ LOGYHOST } & 0.45 & $1.81^{* \star \star}$ \\
\hline & $(1.36)$ & $(3.66)$ \\
\hline$R$-squared & 0.70 & 0.88 \\
\hline Adjusted $R$-squared & 0.59 & 0.67 \\
\hline$F$ test & $6.11^{\star * *}$ & $4.20^{* *}$ \\
\hline
\end{tabular}

Notes: Figures in parentheses are the $t$-ratios. $* * *, * *$, and $*$ indicate significance at the 1,5 , and 10 percent significance levels, respectively.

become investment rather than consumption smoothing. Inclusion of the earlier period, from 1963 to 1978, reveals, however, that variables such as the level of domestic income or stock of workers abroad also had significant effects on remittances. This is an expected result, because, coupled with the decline in worker migration over time, the family ties of migrant workers would be expected to have weakened between host and home countries.

Like Wahba's (1991) observations on Egypt, we also observe that interest rate differentials have also had a positive effect on WR. In addition, the findings in this 
paper support Glytsos' (1988) claim that policy variables have a short-run effect. Comparing the findings with those of Straubhaar (1986), however, is difficult, as our analysis differs not only in the time periods employed but also in that we use time-series techniques to concentrate on short-run econometric modeling. Nevertheless, while our findings support Straubhaar in terms of the significance of homecountry political stability and host-country economic status, unlike Straubhaar, the responsiveness of remittances to exchange rate overvaluation and interest rate differentials is captured in our analysis.

\section{Conclusions}

WR flows to Turkey have increased since the 1960s, amounting to a significant proportion of Turkish imports. This paper examines the effect of various macroeconomic variables on these flows. Our empirical findings indicate that, for the 1979-93 period, macroeconomic variables - specifically home- and host-country incomes, black market premium, interest rate differentials, growth, inflation, and periods of military regimes - significantly affect remittance flows. Among them, the negatively significant effects of black market premium, inflation, and military regimes, as well as the positive significant effect of growth, point at the importance of sound exchange rate policies and economic and political stability in attracting remittance flows. While these observations, which are mostly prevalent in the 1979-93 period, indicate that the investment motive is more effective for WR flows to Turkey, consumption smoothing also remains an effective motive since 1965 , as seen in the negative coefficient of the domestic income.

Based on the findings of this paper, we conclude that macroeconomic variables significantly impact on WR for the Turkish case, indicating that governments of

labor-exporting countries can influence the inflow of remittances by means of appropriate macroeconomic policies. The empirical findings in this paper also imply that improving financial intermediation and preventing exchange rate misalignments help increase the inflow of remittances.

\section{Notes}

1. According to the World Bank, workers' remittances are composed of three types of flows: workers' remittances (transfers of money by those workers who reside abroad for more than one year); compensation of workers (gross earnings of workers residing abroad for less than one year, including the value in-kind benefits, such as housing and payroll taxes); and migrant transfers (net worth of migrants who move from one country to another).

2. For example, in terms of percent of foreign direct investment, net WR were 245 percent in Portugal, 460 percent in Turkey, and 687 percent in Egypt during the 1990s. For more detail, see Neyapti (2004).

3. The work by Aydas (2002) cited is a master's thesis, which was supervised by MetinOzcan and Neyapti, Bilkent University. Though this paper is based on Aydas's master's thesis, the econometric modeling employed in the current paper is improved by the addition of further variables. 
4. Based on the Central Bank of the Turkish Republic database, the respective figures for the 1970s were 27 percent of GDP and 60 percent of the labor force, and for the 1980s, 20 percent of GDP and 50 percent of the labor force, revealing that the major reduction in the GDP share of agriculture came mainly during the 1960s, with a continuing per labor value added in agriculture thereafter, which may have further contributed to labor migration.

5. Between May 1960 and September 1980, ten changes of government took place.

6. The Dresdner scheme was based on the 1976 agreement between the Central Bank of the Turkish Republic and the Dresdner Bank of Germany to allow migrant Turkish workers to open special interest-earning accounts at the central bank via Dresdner Bank. This had the effect of assisting Turkey in managing its foreign exchange reserves, especially useful during the 1970s oil crises. Although the scheme ended in 1984, due to the disapproval of the German authorities, similar schemes, such as super exchange accounts, have continued, though with many changes in their terms over time (Cetin 2004). Our data, nevertheless, do not include these accounts in the central bank, but are rather based on WR in the balance of payments.

7. See, for example, Lucas and Stark (1985); Stark (1980; 1983); Stark and Katz (1985); Stark and Levhari (1982); Stark and Lucas (1987); and Stark et al. (1985).

8. See Aydas (2002) for a detailed survey of the literature.

9. See, for example, Elbadawi and Rocha (1992), Straubhaar (1986), and Swamy (1981).

10. YHOST is based on the weighted average of the eleven countries that are chosen based on the rankings of countries that receive the highest number of Turkish workers (compiled by Aydas 2002). The weights are the relative sizes of the stock of workers in those countries, and vary over time. Those data are reported in Aydas (2002) and are available from the author upon request. As for INTDIF, due to a lack of data, interest rate and exchange rate incentives provided to the migrant workers are not taken into consideration.

11. These two variables constitute the main differences in the results obtained here and those in Aydas (2002).

12. When the dependent variable is $\triangle L O G R E M$, the stock of workers abroad, represented by WORKER, is also included in the equation.

13. Year 1994 is lost due to first differencing.

\section{References}

Abadan-Unat, N. 1976. Turkish Workers in Europe 1960-1975: A Socio-Economic Reappraisal. Leiden: E.J. Brill.

Adler, S. 1981. "A Turkish Conundrum: Emigration, Politics and Development, 19611980.” World Employment Programme Research Working Paper, International Labour Organisation, Geneva.

Aydas, O.T. 2002. "Determinants of Workers Remittances: The Case of Turkey.” Master's thesis, Bilkent University, Ankara.

Cetin, B. 2004. "Kredi Mektuplu Doviz Tevdiat Hesabi Sistemi ve Yeniden Yapilandirilmasi” [The System of Foreign Currency Accounts with Credit Letter and Its Reform]. Central Bank of the Turkish Republic, Ankara.

Chandavarkar, A.G. 1980. "Use of Migrants Remittances in Labor-Exporting Countries." Finance and Development 17 (June): 36-39.

Djajic, S. 1989. "Migrants in a Guest-Worker System." Journal of Development Economics 31 (August): 327-339.

Djajic, S., and R. Milbourne. 1988. "A General Equilibrium Model of Guest-Worker Migration: The Source Country Perspective." Journal of International Economics 25, no. 11 (November): 335-351. 
Elbadawi, I.A., and R. Rocha. 1992. "Determinants of Expatriate Workers' Remittances in North Africa and Europe.” World Bank Policy Research Working Paper 1038, Washington, DC.

El-Sakka, M.I.T., and Robert McNabb. 1999. "The Macroeconomic Determinants of Emigrant Remittances.” World Development 27, no. 8: 1493-1502.

Etzinger, H. 1978. "Return Migration from West European to Mediterranean Countries." International Labor Office, Working Paper 23, Geneva.

Glytsos, N. 1988. "Remittances in Temporary Migration: A Theoretical Mode and Its Testing with the Greek-German Experience." Weltwirtschafliches Archiv 124, no. 3: 524-548.

Gokdere, A.Y. 1978. "Yabanci Ulkerlere Isgucu Akimi ve Turk Ekonomisi Uzerine Etkileri” [Labor Migration and Its Effects on the Turkish Economy]. Turkiye Is Bankasi Kultur Yayinlari, no. 196.

Hoddinott, J. 1992. "Modelling Remittance Flows in Kenya." Journal of African Economics 1, no. 1: 233-270.

Ilahi, N., and S. Jafarey. 1999. "Guest-Worker Migration, Remittances and the Extended Family: Evidence from Pakistan.” Journal of Development Economics 58, no. 2 (April): 485-512.

International Labor Organization. 2000. Bulletin of International Migration. Geneva.

Istatistik Yıllgı, Çalışma ve Sosyal Güvenlik Bakanlıgı, Türkiye Iş Kurumu Genel Müdürlüü [Annual Statistic Report, Ministry of Labor and Social Security]. Mart 2001.

Katselli, L., and N. Glytsos. 1986. "Theoretical and Empirical Determinants of International Labour Mobility: A Greek-German Perspective." Center for Economic Policy Research, Discussion Paper 148, London.

Knowles, J., and L. Anker. 1981. "An Analysis of Income Transfers in a Developing Country: The Case of Kenya." Journal of Development Economics 8, no. 2 (April): 205-226.

Lucas, R., and O. Stark. 1985. "Motivations to Remit: Evidence from Botswana." Journal of Political Economy 93, no. 5 (October): 901-918.

Martin, P.L. 1992. "The Unfinished Story: Turkish Labor Migration to Western Europe." World Employment Programme Research Working Paper, International Labour Organisation, Geneva.

Miller, D.R. 1976. "International Migration of Turkish Workers.” International Labor Office, Working Paper 41, Geneva.

Murinde, V. 1993. "Budgeting and Financial Policy Potency amid Structural Bottlenecks." World Development 21, no. 5 (May): 841-859.

Neyapti, B. 2004. “Trends in Workers Remittances: A World-Wide Overview." Emerging Markets Finance and Trade 40, no. 2 (March-April): 83-90.

Paine, S. 1974. "Exporting Workers: The Turkish Case." Department of Applied Economics, University of Cambridge Occasional Papers no. 41.

Penninx, R. 1982. "A Critical Review of Theory and Practice: The Case of Turkey." International Migration Review 16, no. 4 (Winter): 781-818.

Russell, S.S. 1986. "Remittances from International Migration: A Review in Perspective." World Development 14, no. 6: 677-696.

Stark, O. 1980. "On the Role of Rural to Urban Migration in Rural Development." Journal of Development Studies 16 (April): 369-374.

- 1983. "Towards a Theory of Remittances." Harvard Institute of Economic Research Discussion Paper Series.

Stark, O., and E. Katz. 1985. "A Theory of Remittances and Migration.” Harvard University Migration and Development Program Discussion Paper no. 18. 
Stark, O., and D. Levhari. 1982. "On Migration and Risk in LDCs.” Economic Development and Cultural Change 31, no. 1 (October): 191-196.

Stark, O., and R. Lucas. 1987. "Migration, Remittances and the Family." Harvard University, Migration and Development Program Discussion Paper no. 28. Cambridge, MA.

Stark, O.; J.E. Taylor; and S. Yitzhaki. 1985. "Remittances and Inequality." Harvard Institute of Economic Research, Cambridge, MA.

Straubhaar, T. 1986. "The Determinants of Workers' Remittances: The Case of Turkey." Weltwirtschafliches Archiv 122, no. 4: 728-740.

Swamy, G. 1981. “International Migrant Workers' Remittances: Issues and Prospects.” World Bank Staff Working Paper 481, Washington, DC.

Wahba, S. 1991. "What Determines Workers' Remittances." Finance and Development 28, no. 4: 41-44.

Werth, M., and N. Yalçıntaş. 1978. "Migration and Re-integration.” International Labor Office Working Paper 29, Geneva. 
